\title{
Corrigendum: Long-term NMDAR antagonism correlates reduced astrocytic glutamate uptake with anxiety-like phenotype
}

\begin{abstract}
Eduardo R. Zimmer ${ }^{1}$, Vitor R. Torrez ${ }^{1}$, Eduardo Kalinine ${ }^{1,2}$, Marina C. Augustin ${ }^{1}$, Kamila C. Zenki ${ }^{1}$, Roberto F. Almeida ${ }^{1}$, Gisele Hansel ${ }^{1}$, Alexandre P. Muller ${ }^{1,3}$, Diogo O. Souza ${ }^{1}$, Rodrigo Machado-Vieira ${ }^{4,5,6}$ and Luis V. Portela ${ }^{1 *}$

${ }^{1}$ Department of Biochemistry, Universidade Federal do Rio Grande do Sul, Porto Alegre, Brazil, ${ }^{2}$ Department of Physiology, Universidade Federal do Sergipe, São Cristovão, Brazil, ${ }^{3}$ Laboratory of Exercise, Biochemistry and Physiology, Universidade do Extremo Sul Catarinense, Criciúma, Brazil, ${ }^{4}$ Laboratory of Neuroscience, LIM-27, Institute and Department of Psychiatry, Universidade de São Paulo, São Paulo, Brazil, ${ }^{5}$ Center for Interdisciplinary Research on Applied Neurosciences (NAPNA), Universidade de São Paulo, São Paulo, Brazil, ${ }^{6}$ Experimental Therapeutics and Pathophysiology Branch, National Institute of Mental Health, Bethesda, MD, USA
\end{abstract}

Keywords: anxiety, astrocytes, behavior, glutamate, memantine

\section{A corrigendum on}

Long-term NMDAR antagonism correlates reduced astrocytic glutamate uptake with anxiety-like phenotype

by Zimmer, E. R., Torrez, V. R., Kalinine, E., Augustin, M. C., Zenki, K. C., Almeida, R. F., et al. (2015). Front. Cell. Neurosci. 9:219. doi: 10.3389/fncel.2015.00219

OPEN ACCESS

Edited and reviewed by: Johann Steiner, University of Magdeburg, Germany

${ }^{*}$ Correspondence: Luis V. Portela roskaportela@gmail.com

Received: 16 March 2016 Accepted: 24 March 2016 Published: 11 April 2016

Citation: Zimmer ER, Torrez VR, Kalinine E, Augustin MC, Zenki KC, Almeida RF,

Hansel G, Muller AP, Souza DO,

Machado-Vieira $R$ and Portela LV

(2016) Corrigendum: Long-term

NMDAR antagonism correlates reduced astrocytic glutamate uptake with anxiety-like phenotype.

Front. Cell. Neurosci. 10:93. doi: 10.3389/fncel.2016.00093
In the subsection "Glutamate Uptake Assay," the greek letter micro (symbol $\mu$ ) was accidentally deleted twice probably due to software incompatibility. The correct sentence should read: "Afterwards, 0.66 and $0.33 \mu \mathrm{Ci} \mathrm{ml}^{-1} \mathrm{~L}-\left[{ }^{3} \mathrm{H}\right]$ glutamate were added to a final $100 \mu M$ concentration of glutamate for incubation with hippocampal and cortical samples, respectively." This correction does not affect the scientific relevance of the results.

\section{AUTHOR CONTRIBUTIONS}

EZ was responsible for the design, acquisition, analysis, interpretation, drafting, and approval of the final version of the manuscript. VT, EK, MA, KZ, RA, and GH were responsible for acquisition, analysis, interpretation, and approval of the final version of the manuscript. AM, DS, and RM were responsible for interpretation, drafting, critical revision, and approval of the final version of the manuscript. LP was responsible for the design, interpretation, drafting, critical revision, and approval of the final version of the manuscript.

\section{FUNDING}

This work was supported by the following Brazilian agencies and grants: National Counsel of Technological and Scientific Development (CNPq), CAPES, FAPERGS, Brazilian Institute of 
Neuroscience (IBNnet), FINEP, and National Institute of Science and Technology (INCT) - Excitotoxicity and Neuroprotection.

Conflict of Interest Statement: The authors declare that the research was conducted in the absence of any commercial or financial relationships that could be construed as a potential conflict of interest.
Copyright $\odot 2016$ Zimmer, Torrez, Kalinine, Augustin, Zenki, Almeida, Hansel, Muller, Souza, Machado-Vieira and Portela. This is an open-access article distributed under the terms of the Creative Commons Attribution License (CC BY). The use, distribution or reproduction in other forums is permitted, provided the original author(s) or licensor are credited and that the original publication in this journal is cited, in accordance with accepted academic practice. No use, distribution or reproduction is permitted which does not comply with these terms. 